\title{
Rabbani Character as a Medium to Establish Spiritual Intelligence in the Learning Process
}

\author{
Sitti Amrah \\ Muhammadiyah University of Parepare \\ amrahrahmuddin@gmail.com
}

\author{
Umar Sulaiman \\ State Polytechnic of Kupang \\ umarsulaiman821@gmail.com
}

\begin{abstract}
The Rabbani Character is essentially an activity emphasizing divine attributes in the learning process through spiritual values; honesty, sincerity, affection, tolerance, discipline, hardworking, creativity, independent, democratic, and communicative. It mainly focuses on the affective aspect (heart). Furthermore, Rabbani character has positive implications to cultivate spiritual intelligence in the instructional process. The main objective to optimize Rabbani character in the learning context is to actualize the potential of the students' spirituality. It, then, increases the students' sensitivity and religious responsiveness through exemplary values, habits, advices, warnings, and punishments. Attempts to apply Rabbani character education could be initiated through the development of religious education curriculum. For example, a school could familiarize Islamic values through the creation of a cool and beautiful school environment and the application of discipline values in the learning activity. The research applied descriptive-analytical and an actual interview method to gain the maximum outcome.
\end{abstract}

Keywords: Rabbani Character, Spiritual Intelligence, Religious Culture

\section{INTRODUCTION}

Nowadays, people, as widely discusssed in various formal forum, face complex and multidimensional crisis. Its facets touch every aspect of life. This crisis includes intellectual, moral, and spiritual dimensions. Fritjof Capra argued that these crisis, including the spiritual crisis, have never occured before in the human historical record. Danah Zohar underlined this crisis era is marked by the emergence of a fundamental crisis in the modern society. Daniel Goleman mentions that the last years of this millennium introduced what is called the "age of melancholy" as the XXI century to be "the age of anxiety." International data showed what appears to be a modern people depression caused by the adoption of modern lifestyles around the world. Danah Zohar considered the modern culture is spiritually dumb, both in the West and East countries. This was commonly affected by the West[1]-[2].
Modern people, according to Hussein Nasr, is in the periphery of their existence moving away from itself center, and the center is spiritual[3]-[4].moreover, he elaborated there are at least two things that plague modern humans today, namely the empty of spiritual values and the strictness of the materialistic values in their lives or vice versa. And, spiritual aspects dominated and released material aspects [5].The spiritual crisis of modern people, much inspired by naturalism, materialism, and positivism, has found its momentum because modern science and the technology carries a secular view [6]. Consequently, it will lead to the destruction of norms and rules of society which become the common guideline in life [7]-[8].

Daniel Bell voiced anxiety and regreted over the impact of modernization that has uprooted and eliminated the noble values of traditional life to be replaced by the modernity values of bourgeois-urban society. The sociologists saw the symptom of the modern human crisis in the society representing a setback for life progress, and that is undeniably social reality [9]. There is deterioration in the fabric of human behavioral structures, taking place firstly on a personal level in term of motives, perceptions, and responses, including status and role conflicts. Secondly, it deals with norms related to the destruction of the rules that must be followed to behave properly. Emile Durkheim called it as the life without norms. At the cultural level, the crisis is a shift in the values and knowledge of society which William F. Ogburn called the cultural gap symptom or cultural $\operatorname{lag}[10]$.

\section{METHOD}

The research method was qualitative with a philosophical-normative, sociological and anthropological approaches. The data collection technique was an actual interview. Then, the data was analyzed using the process of searching and arranging systematically the data obtained from interviews, field notes, and documentation. After that, they were organized into categories, describing units, synthesizing and arranging into patterns, to categorize those patterns before conclusions were made. 


\section{RESULT}

\section{The concept of Rabbani Character and Spiritual Intelligence}

The term Rabbani Character (Ibn Faris Zakaria 1399: 329) and its equivalent are always referred to the formation of noble and praiseworthy human behavior. Moral character, according to Ibn Miskawayh (1398: 25) and Imam Al-Ghazali (2004: 70), is a mental attitude containing the impetus to do something without careful thinking and consideration .Mental attitude is divided into two. they come from the character and habit or practice. Morals derived from character rarely produce a commendable morality; mostly bad morals. However, practice or habit characters can result in a commendable morality. Therefore, Ibn Miskawayh emphasizes the importance of education to form good morals. He attaches the importence of education to childhood, which he says it is the link between the animal and the human soul.

The character education of Rabbani emphasizes the functionality of Divinity properties in the learning activity through the forming of spiritual values, namely; honesty, sincerity, affection, tolerance, discipline, hard working, creativity, independent, democracy and communication. It also higlights the affective (heart) aspect. Due to the emphasizing on the locus of the heart, it will eventually emerge the values of attitudes, ethics, beliefs, feelings, and morals. Affective education (heart), one of the goals of islamic education, can encourage students to have both emotional and intellectual intelligence, so they can broaden their understanding of religious knowledge. Then, they will be encouraged to apply them to shape their moral (ahklaq) and personality.

\section{Strategies to Establishing Rabbani Character (Building Spiritual Intelligence)}

The Rabbani character education prioritizing the process of knowledge transmission raises concerns among the educators. As Muhaimin (2009: 106) underlined the learning process of Islamic education in schools is more verbal and formal or just a patch. The methodology has no a substantial change from the past time up to now. On the other hand, society undergo many changes. The approach of the education tends to be normative without considering the socio-cultural context. Thus, learners become less appreciate towards religion values and use them as a living value in everyday life. Furthermore, The evaluation system merely focuses on the students' exam results. In other words, it tends to prioritize a cognitive aspect and the evaluation rarely question the spiritual values implementation in everyday life.

Education is really a process in which the learners are able to adapt to their environment and they have some sort of change allowing him to contribute more the community. Therefore, The efforts to raise the character education of Rabbani based on Spiritual Quotient can be initiated through the development of religious culture in the education environment.
Ngainun Naim (2009: 17) highlighted several methods to instill religious values at school. First, the religious culture should be routinely implemented every day in the learning process at school. Secondly, the school need to create a supportive educational place, such as laboratory, to develop religious education .Third, religious education is not just formally delivered when learners attending religious course, but it can also be taught outside the class. Fourth, the creation of the religious atmosphere is introduced so learners have a through understanding and know proper procedures of the religious practice in everyday life. Fifth, the students are provided with the opportunity to express their talents, interests, and creativity, related with religious arts, such as reading Qur'an with songs, reciting ninety-nine names of Allah (asmaulhusna), calling for prayer (adzan), Qur'an recitation (tilawa), and so forth. Sixth, the school conducts various competition on Islamic education topics to familiarize and train the students' courage, understanding and knowledge about Islam. Seventh, there should be held artistic activities, such as music and dance because art is meaningful and relevant into life.

\section{Application of Rabbani Character Model to Shape Students' Spiritual Intelligence at Islamic Primary School of SDIT Insan Madani Palopo City}

From the attempt (Ikhtiar) to know the application of Rabbani character model to shape the spiritual intelligence of students at SDIT Insan Madani Islamic Elementary School, Palopo City, then, it was found some variables that influence and contribute in the learning process. They included vision and mission of SDAN Insan Madani Palopo City, principal performance, Rabbani character form applied in the effort to form spiritual intelligence, supports and challenges to apply Rabbani character, the patterns of cooperation between the Principal, teachers, and the community, as well as various other factors. The applied analysis method was interview. Regarding the cultivation of Rabbani character as the basic effort to grow Spiritual Quotient at Islamic Elementary School at Insani Madani Palopo City, according to the school principal, Basaruddin, was emphasizing on aspects of rabbaniyah (divinity values) and insaniah (humanitarian values) through pre-eminent programs.

In relation to these excellent programs, when conducting research at the school, the researchers found a fact that the implementation and development of religious cultures have been applied on the school daily routines.The rabbaniyah ritual (divine values) which contributes to the growth of moral values or Islamic character is cultivated by greeting each other among the school community (the students, teachers and staff), praying dhuha (morning sunnah prayer) and dzuhur (mid-day compulsory prayer), wearing uniform based on the Islamic rules and maintenaning environmental hygiene, fasting, erecting infak (alms) culture every Friday, commemorating of Islamic birthday activities etc. While the humanitarian rituals cultivated at school are honest, work hard, flag ceremonies, class hygiene 
contests, infaq (alms), social assistance for disaster victims and orphanages, as well as voluntary and nonvoluntary social activities. Meanwhile, Rabbani character education developed was commemoration of religious holidays, holding a short time pesantren (islamic boarding school) and breaking the fast together, completion of Holy Al-Qur'an reading and holding the night of faith and piety (mabit).

A series of those activities indicated that the process of learning and religious values education has successfully been being run by the school. This success is supported by strategies and programs that have been initiated and developed. The strategy includes ways how to run the programs. In addition, the school also implements school leadership policy, the implementation of Rabbani in teaching and learning activities in the classroom and in extracurricular activities. Also all the school community are required to hold and do the traditions and behavior of Rabbbani continuously and consistently to create an Islamic culture in the school environment. The parameters showing Rabbani characters at school were successful were due to the increase of the honesty (97\%), discipline (98\%), orphanage and natural disaster victims assistance, mutual respect among school community (97\%), cleanliness and beauty of school (95\%), anniversary of Islamic days (96\%), and parents involvement to the implementation of religious culture in schools $(88 \%)$.

\section{CONCLUSION}

Normatively character is a meaningful character. A character is the union between movement, mind, and feeling and willingness that then generates energy. The character is as human nature, ranging from wishful thinking to energy incarnation. With manliness, man will become an independent person with noble personality and can control himself. Thus, the character of Rabbani is the character emphasizing the function of the Godhead in the learning process through the reinforcement of spiritual values; honesty, sincerity, affection, tolerance, discipline, hard working, creativity, independent, democracy and communication. Because the education emphasizes the locus of the heart, the emergence of the values of attitudes, ethics, beliefs, feelings and moralspiritual intelligence is necessity to deal with the problems in life. Spiritual Quotient is the foundation needed to enable Intelligence Quotient and Emotional Quotient run effectively. A person who possesses spiritual intelligence has a personality based on human values that emit a light to soul. This will illuminate one's attitude, behavior and deeds to become human straight (hanif), optimistic and consistent and beneficial for the surrounding environment.

\section{REFERENCES}

[1] F. Capra, "The Turning Point: A New Vision of Reality," Futurist, 1982.

[2] F. Capra, "Criteria of systems thinking," Futures, 1985.

[3] S. H. Nasr, "Islam and the Environmental Crisis," in The Essential Seyyed Hossein Nasr, 2007.

[4] Y. Zul Azmi and M. Zailani, "Hak Asasi Manusia ( Human Rights ) dalam Menangani Krisis Alam Sekitar: Perspektif Seyyed Hossein Nasr," Int. J. Islam. Thought, 2012.

[5] F. Capra, "Smart by Nature: Schooling for Sustainability," J. Sustain. Educ., 2010.

[6] F. Capra, "Life and Leadership for a Sustainable Community: Lessons on how to sustain life by building and nurturing community," Center for Ecoliteracy, 2010. .

[7] J. King, "SQ: Spiritual intelligence: The ultimate intelligence," Psychol. Psychother., 2002.

[8] D. Claravasanthi \& Mumtaz Begum, "Ramification Of Spiritual Intelligence," Best Int. J. Humanit. Arts, Med. Sci. (BEST IJHAMS) , 2017.

[9] D. Goleman, "Daniel Goleman: liderar con inteligencia emocional," Cap. Hum. Rev. para la Integr. y Desarro. los Recur. humanos, 2005.

[10] D. Goleman, Working with Emotional Intelligence. 1998. 